\title{
Probiotic potential of thermotolerant lactic acid bacteria isolated from "Gari "a cassava-based African fermented food
}

\author{
Bertrand Tatsinkou Fossi ${ }^{1}$, Robert Ndjouenkeu ${ }^{2}$ \\ ${ }^{1}$ Department of Microbiology and Parasitology, University of Buea, POBox 63, Buea, Cameroon. \\ ${ }^{2}$ Department of Food Science and Nutrition, University of Ngaoundere, POBox 455, Ngaoundere, Cameroon.
}

\begin{tabular}{l} 
ARTICLE INFO \\
\hline Article history: \\
Received on: 10/04/2017 \\
Accepted on: 13/06/2017 \\
Available online: 14/08/2017 \\
\hline Key words: \\
Thermotolerant probiotics, \\
"Gari", Antimicrobial activity, \\
Probiotic products, Industrial \\
processing.
\end{tabular}

\section{INTRODUCTION}

Probiotics are defined as live microbial feed supplement that beneficially affects the host by improving its intestinal balance [1, 2]. Most probiotics are lactic bacteria, such as Lactobacillus casei, Lactobacillus plantarum, Lactobacillus acidophilus and Streptococcus lactis [3, 4]. Several research studies have shown that the addition of probiotic sources in the diet provides beneficial effects such as; the inhibition of the proliferation of pathogenic microbes in the digestive tract, the reduction of the blood cholesterol, the improvement of the immune system and the reduction of the risks of cancer of the colon [5-8]. Fermented foods are sources of various microbial strains of food and industrial interest. Previous studies on the fermentation of cassava during the traditional processing reported that lactic acid bacteria are the dominant microflora involved in the change of raw cassava into "Gari"[9]. Cassava largely produced in different regions of Cameroon and

\footnotetext{
* Corresponding Author

E-mail: tatsinkoufossi @yahoo.fr, tatsinkou.fossi @ ubuea.cm
}

particularly in the South West Region of Cameroon is one of the most important source food for the populations. The traditional processing of cassava involves a step of natural fermentation. The fermentation is very important in the making of some cassavabased foods consumed in Cameroon such as, "Gari", "Water fufu", and "Miondo". Several authors have reported on the technological properties of the microorganisms isolated from cassava fermentation, such as the removal of cyanhydric acid initially present in some cultivar of cassava, the hydrolysis of cassava starch into reducing sugars, the production of lactic acid, the change in flavor etc. From our knowledge no studies have been done on the probiotic potential of these technological strains. Many yeasts and lactic acid bacteria with the potential to hydrolyze raw starch have been isolated from cassava fermentation; however there is no information on the probiotic potential of cassava- based fermented food. Moreover very few studies have been devoted to the probiotic potential of thermotolerant/thermophile microorganisms. The development of an accurate technology for the production of probiotics should take into account the viability and stability of the strains used. The viability of probiotic microbial strains in food products is being investigated extensively. 
The industrial production of probiotics should be based on the properties of the microbial strains involved and their ability to with stand stress during industrial processing and storage. Thermophilic/thermotolerant probiotics are of great interest in this area as they can have all the desired characteristics [10].

This study aimed at investigating on the probiotic properties of thermotolerant/thermophile lactic acid bacteria isolated from "Gari".

\section{MATERIALS AND METHODS}

\subsection{Samples collection}

"Gari" samples were collected in different factories dealing with traditional processing of cassava in the South west Region of Cameroon. Forty samples containing about $10 \mathrm{~g}$ each were collected and placed in a polyethylene aseptic bag and transported to the laboratory for the isolation of lactic acid bacteria.

\subsection{Isolation and phenotypic identification of lactic acid bacteria}

LAB was isolated from "Gari" by pour plating method using DeMan Rogosa and Sharpe (MRS) agar. For this purpose, $1 \mathrm{~g}$ of each sample was added to $9 \mathrm{ml}$ of peptone water $(1 \% \mathrm{w} / \mathrm{v})$. A ten-fold serial dilution was performed. One $\mathrm{ml}$ of the diluted sample was aseptically inoculated in sterile petri dish, and then 15 $\mathrm{ml}$ of MRS agar was poured in the plate. After solidification, the plates were incubated at $42{ }^{\circ} \mathrm{C}$ for $48 \mathrm{~h}$ under anaerobic conditions for the growth of thermophilic lactic acid bacteria. After the incubation, catalase test was carried out. Catalase negative colonies which appeared on the plates with distinct morphological characteristics were picked and sub-cultured 2-3 times for their purification. Additional characterizations were performed using Gram staining test and cell morphology examinations. Catalase negative and Gram positive isolates were selected and at kept at$80^{\circ} \mathrm{C}$ in $1.5 \%(\mathrm{v} / \mathrm{v})$ glycerol agar until identification. The determination of carbohydrate fermentation profile of LAB was performed using API $50 \mathrm{CHL}$ kit (BioMerieux, France). The APILAB PLUS database software was used to interpret the results

\subsection{Thermotolerance test}

For the thermotolerance test, a colony of each catalase negative isolate was suspended in $10 \mathrm{ml}$ sterile MRS broth in test tubes and heat at temperatures comprised between 50 and $60{ }^{\circ} \mathrm{C}$ for $1 \mathrm{~h}$, then cools at room temperature and incubated at $37^{\circ} \mathrm{C}$ for $48 \mathrm{~h}$ for normal growth. The growth was measured by reading the absorbance at $600 \mathrm{~nm}$. The absorbance was read using an absorbance microplate reader (BioTek). Colonies suspended in MRS broth without heating were taking as control. The thermotolerance was calculated using the following formula:

$$
\text { Thermotolerance }(\%)=\frac{A}{A_{0}} \times 100
$$

$A$ is the absorbance of at $600 \mathrm{~nm}$ of the pre-heated cell suspension after $48 \mathrm{~h}$ of incubation at $37^{\circ} \mathrm{C}$ and $A_{0}$ is the absorbance of the control at the same wavelength.

\subsection{Antimicrobial activity of LAB}

The antimicrobial activity of LAB was determined by modifying the disc diffusion method of Hamdan and Mikolajcik (1974) [11]. Sterile Wattman paper discs of $5 \mathrm{~mm}$ in diameter were prepared and immersed in the MRS culture broth (Liofilchem Diagnostici) in the presence of the lactic acid bacteria isolates and incubated in a shaker at $37^{\circ} \mathrm{C}, 150 \mathrm{rpm}$ for $24 \mathrm{~h}$. The discs thus prepared were then placed on the surface of Muelller Hinton agar (Liofilchem Diagnostici), pre-inoculated with an indicator strain. The petri dishes were first incubated at $4{ }^{\circ} \mathrm{C}$ for $3 \mathrm{~h}$ to allow diffusion of the antimicrobial agent, and incubated at $42^{\circ} \mathrm{C}$ for 16 h. The discs dipped in MRS broth were used as negative control. Antibiotic discs of Ofloxacin and Azithromycine (positive control) were placed on solidified Muller-Hinton agar seeded with $14 \mathrm{~h}$ cultures of indicator microorganisms and incubated under the same conditions. The indicator organisms used were, Salmonella enterica, Esherichiacoli and Staphylococcus aureus. Their zones of inhibition were evaluated by measuring the diameter of the discs plus the surrounding clear area in millimeters ( $\mathrm{mm}$ ).

\subsection{Tolerance to acidic conditions}

Lactic acid bacteria isolated from "Gari" were inoculated in MRS broth and incubated at $37{ }^{\circ} \mathrm{C}$ for $18 \mathrm{~h}$. The fermenting broth was centrifuged for $10 \mathrm{~min}$ at $5000 \mathrm{rpm}$ and $4^{\circ} \mathrm{C}$. Pellets were properly washed in phosphate-saline buffer (PBS) at $\mathrm{pH} 6.2$. $\mathrm{HCl} 1 \mathrm{~N}$ was used adjust to $\mathrm{pH}$ at 1.0, 1.5, 2.0, 2.5, 3.0 and 6.2 (control pH) with the aid of a pH-meter (Mettler Teledo). The cell pellets (107-108 CFU/ml) were re-suspended in $10 \mathrm{ml}$ of PBS (pH1.0, 2.0,3.0 and 6.2) and incubated at $37^{\circ} \mathrm{C}$ for $1,2,3$ and $4 \mathrm{~h}$. LAB were counted by plating $100 \mu \mathrm{L}$ aliquot of the inoculated PBS solutions at the different tested times on MRS agar incubated at $37 \mathrm{C}$ for $24 \mathrm{~h}$. The experiments were performed in duplicates.

\subsection{Bile tolerance}

Lactic acid bacteria isolated from "Gari" were cultured in MRS broth at $37{ }^{\circ} \mathrm{C}$, for $16-18 \mathrm{~h}$. The fermenting broth was centrifuged for $10 \mathrm{~min}$ at $5000 \mathrm{rpm}$ and $4{ }^{\circ} \mathrm{C}$. Pellets were properly washed in phosphatesaline buffer (PBS at $\mathrm{pH}$ 6.2) and resuspended in PBS ( $\mathrm{pH}$ 6.2). MRS broth was prepared containing two different concentrations of oxgall-bile $(0.15 \%$ and $0.30 \%$ $\mathrm{w} / \mathrm{v})$.

The control was MRS broth prepared without oxgall-bile. The MRS broth were inoculated with $100 \mu$ laliquot of the LAB suspensions $\left(10^{7}-10^{8} \mathrm{CFU} / \mathrm{ml}\right)$ and incubated for $1,2,3$ and $4 \mathrm{~h}$. Then, viable bacteria counts were determined after $24 \mathrm{~h}$ incubation at $37^{\circ} \mathrm{C}$. The experiments were performed in duplicates. In both cases, the survival percentage of LAB was calculated by the following formula: 


$$
\text { Survival }=\frac{\text { Final } C F U / m l}{\text { Control } C F U / m l} \times 100
$$

\section{RESULTS AND DISCUSSION}

A total of 12 catalase negative and gram positive thermotolerant isolates (persistence of growth at $40-60^{\circ} \mathrm{C}$ ) were isolated from "Gari" samples processed in the south west Region of Cameroon. Two isolates, SB1, SB4, were selected as potential probiotic lactic acid bacteria based on their high antagonistic activity against several food borne pathogenic bacteria isolated locally. These selected isolates were respectively identified phenotypically using API $50 \mathrm{CHL}$ BioMerieux kit as strains of Lactobacillus plantarum, and Lactobacillus acidophilus.

The thermotolerance of the microbial strains is shown in Figure 1. SB1 and SB4 were able to tolerate heating temperatures comprised between $40-56^{\circ} \mathrm{C}$ with a percentage higher or equal to about $80 \%$. These temperatures ranges correspond to the temperatures for the processing of some industrial dairy products.

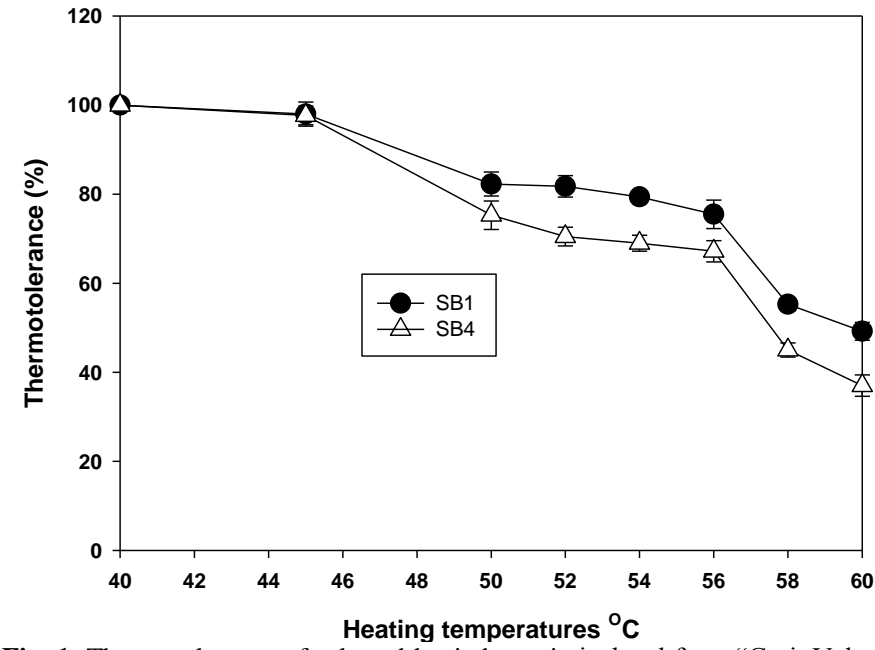

Fig. 1: Thermotolerance of selected lactic bacteria isolated from "Gari. Values are an average of three replicates \pm standard deviation.

The antimicrobial activities against pathogenic bacteria, particularly food borne pathogenic bacteria and food spoilage microorganisms are shown in Figure 2. Lactobacillus plantarum SB1 was active against Escherichia coli BL21, E. coli. Salmonella enterica serovar Enteritidis, Salmonella enterica serovar Typhimurium, Listeria monocytogenes, Staphylococcus aureus and Bacillus Sp. The ability of inhibiting the growth of pathogenic strains is one of the most important probiotic properties common in lactic acid bacteria [12-15]. Scapin et al. [16] have reported similar results in regard to the action of the probiotic strain Lactobacillus acidophilus LA10 against Salmonella Enteritidis SE86 in mice. Bian et al. [17] also reported the antagonistic activity of Lactobacillus helveticus isolated from traditional cheese in Sinkiang China against several food borne pathogens. Our selected lactic acid bacteria are particular compared to many reported probiotic bacteria in that they also showed high activity against Listeria monocytogenes, generally known for its spoilage capability in regards to food products store at ambient or fridge temperature. This suggests that $L$. plantarum SB1 and $L$. acidophilus SB4 can be used not only against intestinal or foodborne pathogenic microorganisms but also against food spoilage bacteria such as Listeria monocytogenes. The inhibitory activity of probiotic bacteria against pathogenic is associated to the production of organic acid or mostly the production of antimicrobial proteins called bacteriocins [18-24]. For the isolates selected in this study, further studies need to be done in order to characterize and identify the nature of their antimicrobials molecules released during growth.

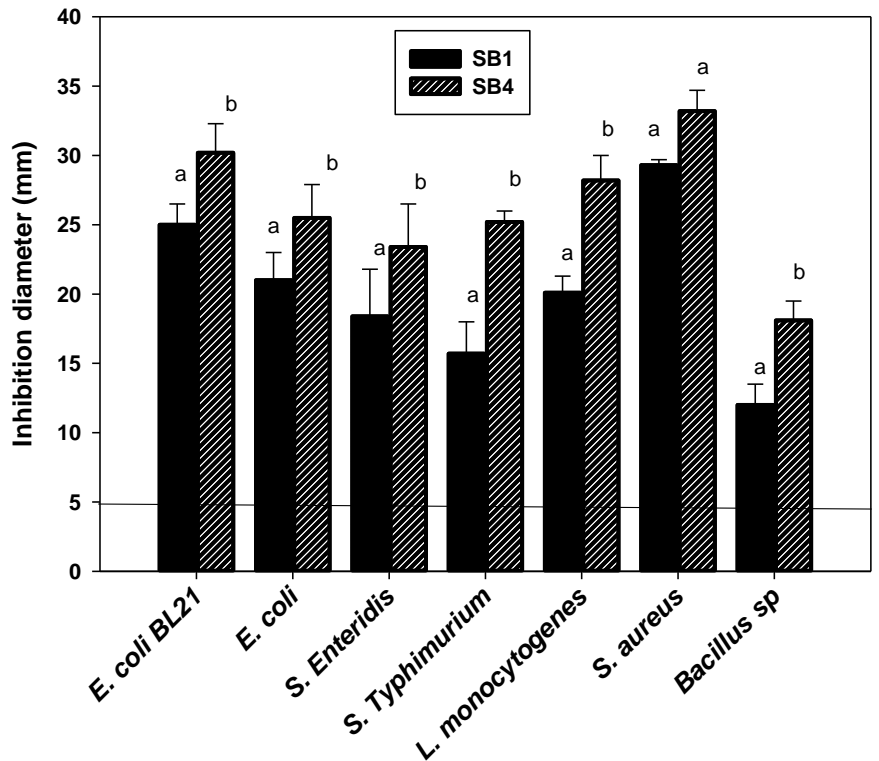

Fig. 2: Diameter of the inhibition zones $(\mathrm{mm})$ around disc containing the cel free supernatant of Lactobacillus plantarum (SB1) and Lactobacillus acidophilus (SB4). Line at $5 \mathrm{~mm}$ represents the dimension of the disc. Values are an average of three replicates \pm standard deviation. Different lowercase letters for the same pathogenic strain indicate a significant difference between the values (analysis of variance test, $\mathrm{p}<0.01$ ).

The isolates $L$ plantarum SB1 and L. acidophilus SB4 selected in this study exhibited good thermotolerance behavior when incubated at temperatures ranged between $40-56^{\circ} \mathrm{C}$. These strains showed acceptable growth in this range of high temperatures. The thermotolerance is a very interesting technological property, since most of the probiotic products are processed at high temperature above $40{ }^{\circ} \mathrm{C}$. The viability of probiotic bacteria is needed to make the probiotic product being effective after consumption or administration. Most of the probiotic products are from dairy industry. The processing of such products involved high temperatures which could lead to the death of probiotic cells making the probiotic product ineffective. Freeze drying is currently the most widespread industrial drying method to produce starter or probiotic cultures. However, spray drying represents a more cost-effective, energy-efficient and productive drying alternative compared to freeze drying. Nevertheless, the high temperatures during spray drying typically lead to lower viability of bacteria than freeze drying [25]. 
(a)

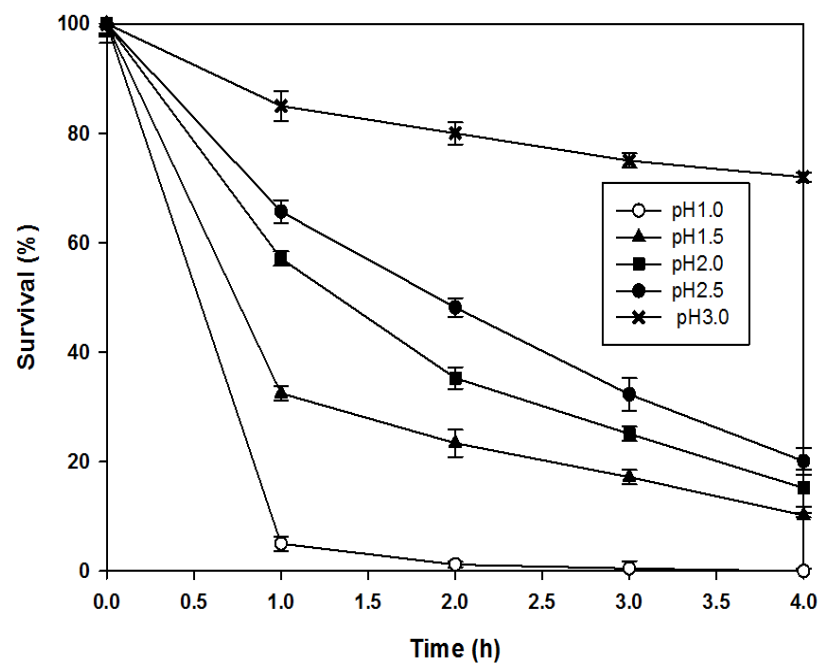

(b)

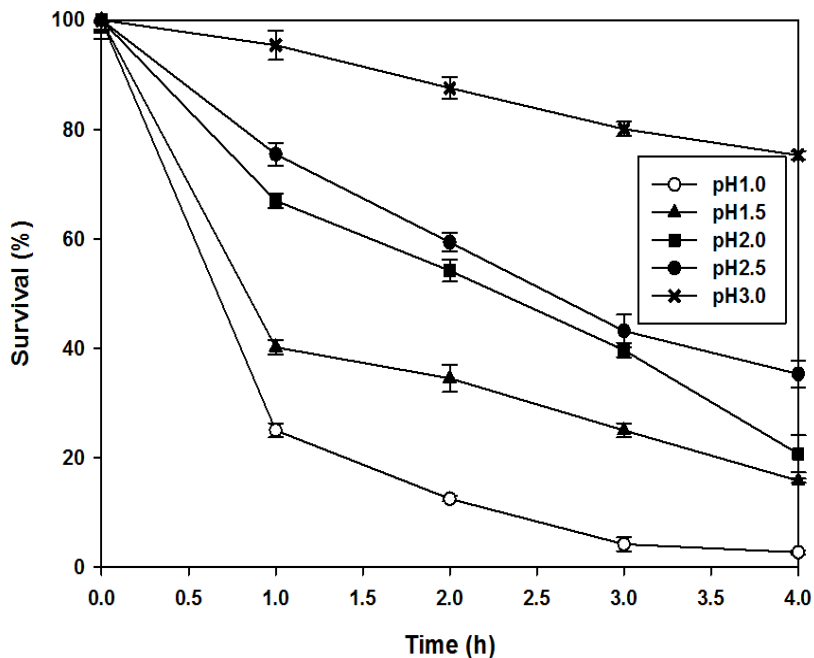

Fig. 3: Survival rate of Lactobacillus plantarumSB1 (a) and Lactobacillus acidophilus (b) in acidic conditions. Values are an average of three replicates \pm standard deviation.

(a)

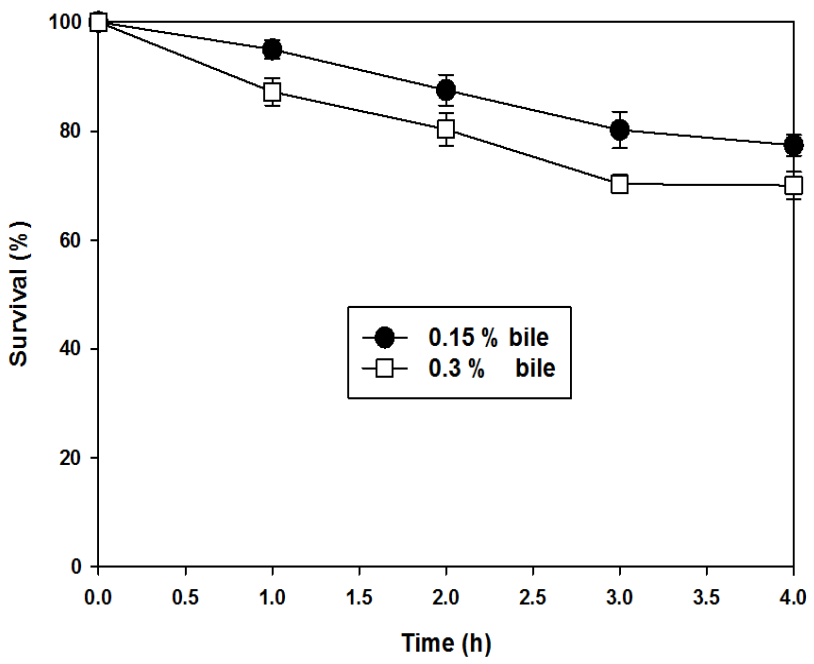

(b)

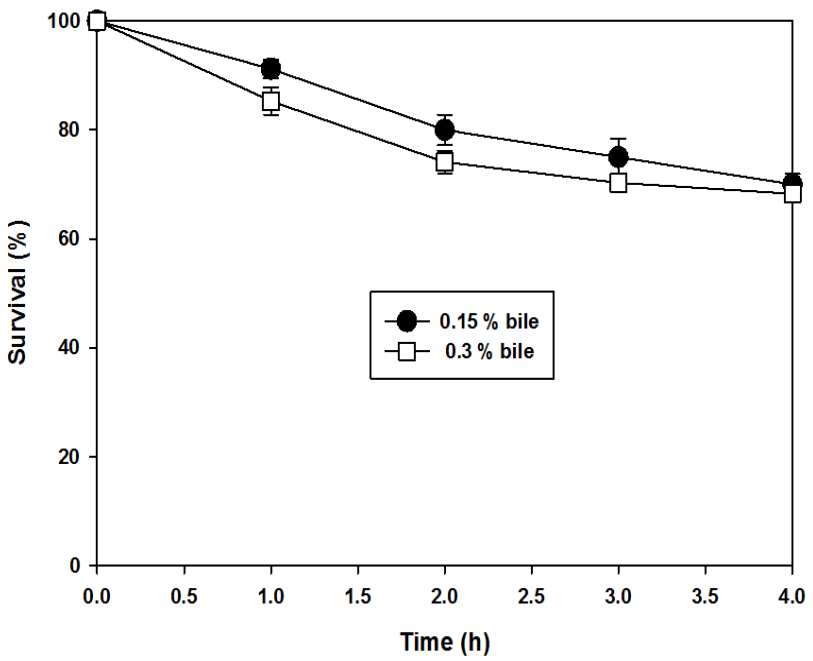

Fig. 4: Survival rate of Lactobacillus plantarum (SB1) (a) and Lactobacillus acidophilus (SB4) (b) in $0.15 \%$ (w/v) and $0.30 \%$ (w/v) oxgall-bile.

Leelavatcharamas et al. [26] have reported on the isolation and characterization of thermotolerant lactic acid bacteria from some Thai fermented food. From our knowledge, very few studies have been devoted to the use of thermotolerant probiotic bacteria. Our study is the first study dealing with the thermotolerance of probiotic lactic acid bacteria isolated from a traditional African fermented food.

The survival of our isolates in acidic conditions showed that both strains (SB1 and SB2) were able to present a survival rate higher than $75 \%$ after incubation for 4 hours at $\mathrm{pH} 2.5$ and $\mathrm{pH}$ 3.0.(Figure 3). The survival was improved at $\mathrm{pH} 3.0$ compared to lower $\mathrm{pH}$ (1.5 to 2.0). They also tolerate bile (Figure 4). Considering that the $\mathrm{pH}$ of the gut is around 3.0, and the fact that food stays for about 2 to 3 hours in the gut, and considering also the resistance of the selected strains (SB1 and SB2) tooxgall-bile, they can be used as probiotic. Similar results were obtained by
Klayraung and Okonogi [27], these authors reported the resistance to bile of the probiotic strains L.fermentum FTL2311 and $L$. fermentum FTL10BR.

\section{CONCLUSION}

This study reveals that "Gari" a traditional processed African food is a potential source of thermotolerant lactic acid bacteria with probiotic properties, especially the inhibition of some food borne pathogenic bacteria. The thermotolerance is actually one of the most important requirements for use of probiotic in industrial processing of foods. Owing the fact that they undergo processing at relative high temperatures, the thermotolerance of the microbial strains involved is needed to make the probiotic products being effective during consumption or administration. The selected thermotolerant lactic acid bacteria L. plantarum 
(SB1) and L acidophilus (SB4) may be used for industrial processing of probiotic food products.

\section{ACKNOWLEDGMENT}

The authors would like to acknowledge the Biotechnology Unit of University of Buea, Cameroon, for providing facilities for research.

\section{Financial support and sponsorship: Nil.}

Conflict of Interests: There are no conflicts of interest.

\section{REFERENCES}

1. Fuller R. Probiotics in human medicine. Gut. 1991; 32:439-442.

2. Fuller R. Probiotics in man and animals. The Journal of applied bacteriology. 1989; 66: 365-378.

3. Zavala L, Golowczyc MA, van Hoorde K, Medrano M, Huys G, Vandamme P, Abraham AG. Selected Lactobacillus strains isolated from sugary and milk kefir reduce Salmonella infection of epithelial cells in vitro. Beneficial microbes. 2016; 7:585-595.

4. Yu Q, Yuan L, Deng J, Yang Q. Lactobacillus protects the integrity of intestinal epithelial barrier damaged by pathogenic bacteria. Frontiers in cellular and infection microbiology. 2015; 5:26.

5. Gorbach SL. Probiotics and gastrointestinal health. The American journal of gastroenterology. 2000; 95:S2-4.

6. Chen CC, Lin WC, Kong MS, Shi HN, Walker WA, Lin CY, Huang $\mathrm{CT}$, et al. Oral inoculation of probiotics Lactobacillus acidophilus NCFM suppresses tumour growth both in segmental orthotopic colon cancer and extra-intestinal tissue. The British journal of nutrition. 2012; 107:1623-1634.

7. Bolognani F, Rumney CJ, Pool-Zobel BL, Rowland IR. Effect of lactobacilli, bifidobacteria and inulin on the formation of aberrant crypt foci in rats. European journal of nutrition. 2001; 40:293-300.

8. Behnsen J, Deriu E, Sassone-Corsi M, Raffatellu M. Probiotics: properties, examples, and specific applications. Cold Spring Harbor perspectives in medicine. 2013; 3:a010074.

9. Ayodej BD, Piccirillo C, Ferraro V, Moreira PR, Obadina AO, Sanni LO, Pintado MME. Screening and molecular identification of lactic acid bacteria from gari and fufu and gari effluents. Ann Microbiol. 2017; 67:123-133.

10. Ramirez-Chavarin ML, Wacher C, Eslava-Campos CA, PerezChabela ML. Probiotic potential of thermotolerant lactic acid bacteria strains isolated from cooked meat products. International Food Research Journal. 2013; 20:991-1000.

11. IY H, EM M. Acidolin: an antibiotic produced by Lactobacillus acidophilus. J Antibiot. 1974; 8:631-636.

12. Zhang W, Liu M, Dai X. Biological characteristics and probiotic effect of Leuconostoc lactis strain isolated from the intestine of black porgy fish. Brazilian journal of microbiology. 2013; 44:685-691.

13. Turpin W, Humblot C, Thomas M, Guyot JP. Lactobacilli as multifaceted probiotics with poorly disclosed molecular mechanisms. International journal of food microbiology. 2010; 143:87-102.

14. Sanz Y, Nadal I, Sanchez E. Probiotics as drugs against human gastrointestinal infections. Recent patents on anti-infective drug discovery. 2007; 2:148-156.
15. Reis NA, Saraiva MA, Duarte EA, de Carvalho EA, Vieira BB, Evangelista-Barreto NS. Probiotic properties of lactic acid bacteria isolated from human milk. Journal of applied microbiology 2016; 121:811-820.

16. Scapin D, Grando WF, Rossi EM, Perez KJ, Malheiros Pda S, Tondo EC. Antagonistic activity of Lactobacillus acidophilus LA10 against Salmonella enterica serovar Enteritidis SE86 in mice. Brazilian journal of microbiology. 2013; 44:57-61.

17. Bian X, Evivie SE, Muhammad Z, Luo GW, Liang HZ, Wang NN, Huo GC. In vitro assessment of the antimicrobial potentials of Lactobacillus helveticus strains isolated from traditional cheese in Sinkiang China against food-borne pathogens. Food \& function. 2016; 7:789-797.

18. Zoumpopoulou G, Pepelassi E, Papaioannou W, Georgalaki M, Maragkoudakis PA, Tarantilis PA, Polissiou M, et al. Incidence of Bacteriocins Produced by Food-Related Lactic Acid Bacteria Active towards Oral Pathogens. International journal of molecular sciences. $2013 ; 14: 4640-4654$.

19. Zoric Peternel M, Canzek Majhenic A, Holo H, Nes IF, Salehian Z, Berlec A, Rogelj I. Wide-Inhibitory Spectra Bacteriocins Produced by Lactobacillus gasseri K7. Probiotics and antimicrobial proteins 2010, 2:233-240.

20. Zheng J, Ganzle MG, Lin XB, Ruan L, Sun M. Diversity and dynamics of bacteriocins from human microbiome. Environmental microbiology. 2015; 17:2133-2143.

21. Uymaz B, Akkoc N, Akcelik M. Partial characterization of bacteriocins produced by two Lactobacilus strains with probiotic properties. Acta biologica Hungarica. 2011; 62:95-105.

22. Taniguchi M, Ishiyama $Y$, Takata $T$, Nakanishi $T$, Kaneoke M, Watanabe K, Yanagida F, et al. Growth-inhibition of hiochi bacteria in namazake (raw sake) by bacteriocins from lactic acid bacteria. Journal of bioscience and bioengineering. 2010; 109:570-575.

23. Cavera VL, Arthur TD, Kashtanov D, Chikindas ML. Bacteriocins and their position in the next wave of conventional antibiotics. International journal of antimicrobial agents. 2015; 46:494-501.

24. Bruce JB, West SA, Griffin AS. Bacteriocins and the assembly of natural Pseudomonas fluorescens populations. Journal of evolutionary biology. 2017; 30:352-360.

25. Yang Y, Huang S, Wang J, Jan G, Jeantet R, Chen XD. Mg2+ improves the thermotolerance of probiotic Lactobacillus rhamnosus GG, Lactobacillus casei Zhang and Lactobacillus plantarum P-8. Letters in applied microbiology. 2017; 64:283-288.

26. Leelavatcharamas V, Arbsuwan N, Apiraksakorn J, Laopaiboon P, Kishida M. Thermotolerant bacteriocin-producing lactic acid bacteria isolated from thai local fermented foods and their bacteriocin productivity. Biocontrol science. 2011; 16:33-40.

27. Klayraung S, Okonogi S. Antibacterial and Antioxidant Activities of Acid and Bile Resistant Strains of Lactobacillus fermentum Isolated from Miang. Brazilian journal of microbiology. 2009; 40:757-766.

\section{How to cite this article:}

Fossi BT, Ndjouenkeu R. Probiotic potential of thermotolerant lactic acid bacteria isolated from "Gari "a cassava-based African fermented food. J App Biol Biotech. 2017; 5 (04): 001-005. 